\title{
OWNERSHIP OF EVOLVED GAS IN SPLIT TITLE SITUATIONS
}

JAMES M. PASIEKA AND N. GLENN CAMERON*

This paper analyzes the ownership of evolved gas where ownership of the petroleum rights has been severed from the mineral title. How 'split titles' arise and the geophysical phenomenon of evolved gas are discussed briefly. The main focus of the paper is the statutory and common law considerations concerning the ownership of evolved gas. The effects of errors in payment of royalties are also examined.

\section{TABLE OF CONTENTS}

I. INTRODUCTION

II. HOW DO “SPLIT TITLE”' LEASES ARISE?

III. WHAT IS EVOLVED GAS?

IV. OWNERSHIP OF EVOLVED GAS 22

A. STATUTORY CONSIDERATIONS 22

B. AT COMMON LAW 23

1. The Borys Decision 23

2. The Rule of Capture $\quad 26$

3. American Authorities 26

V. EFFECT OF ERRORS IN PAYMENT 29

A. THE STATUS OF THE NATURAL GAS LEASE 30

B. RECOVERY OF MONIES PAID IN ERROR 31

C. FURTHER ROYALTIES ON EVOLVED GAS 32

VI. CONCLUSIONS 32

\section{INTRODUCTION}

Petroleum and natural gas are distinct substances. Typically petroleum is found in a liquid state and natural gas is found in a gaseous state. The physical form or "phase" of natural gas can change however. Natural gas can be a liquid in the reservoir and a gas on the surface. Natural gas can also be transformed from a liquid to a gas in the reservoir as pressure within the reservoir declines due to the production of petroleum. Natural gas that transforms from a liquid to a gaseous state and escapes from solution with petroleum in the reservoir before such petroleum is produced is referred to as "evolved gas".

In Alberta petroleum and natural gas reserves underlying a particular property are usually owned by the same party. In some cases however, ownership of petroleum and natural gas has been severed into separate titles.

Where there is separate ownership of the petroleum and natural gas underlying a property, the question of which mineral owner is entitled to the natural gas produced

* Manager, Legal Services, Husky Oil Operations Ltd. and Partner, Code Hunter respectively. 
[VOL. XXIX, NO. 1

from a reservoir containing both substances can be complicated by the physical transformations of natural gas that can occur over time.

Recently, owners of natural gas in such split title situations have claimed to be the owners of any evolved gas that might be produced.

This paper analyzes the ownership of evolved gas where ownership of the petroleum rights has been severed from the balance of the mineral title. The paper will commence with a brief discussion of how such "split title" situations arise and the geophysical phenomena of "evolved gas". This will be followed by a consideration of the statute and common law concerning the ownership of evolved gas. Some brief comments will also be made concerning the effect of errors in payment of royalties where royalties regarding the production of evolved gas may have been mistakenly paid to the wrong persons. Finally, some conclusions respecting these issues will be summarized.

\section{HOW DO “SPLIT TITLE”' LEASES ARISE?}

"Split title" leases occur in freehold mineral titles where the ownership of the mines and minerals is divided between petroleum and natural gas. This separation of ownership usually arises on the transfer of a portion of minerals underlying a property. An exclusion from the transfer creating the split mineral title is usually made by way of reservation. The holder of the entire mines and minerals excepts from the transfer "petroleum" or "petroleum, coal and valuable stone" or some other like reservation. The balance of the mines and minerals is transferred to the transferee. Such transferee accordingly owns all mines and minerals excepting those reserved to the transferor.

In addition to separate ownership of such mines and minerals, the division of title in this way can also result in separate leases being granted for the exploration for production of petroleum and natural gas.

Many of the split title mineral interests that exist in Alberta today arise from dispositions of the Canadian Pacific Railway Company's land holdings in Western Canada. Upon its organization the Canadian Pacific Railway Company (the "CPR") was the recipient from Canada by way of subsidy of approximately 22 million acres of land, including the mines and minerals contained in such properties. Other smaller colonization railways received similar but smaller grants of land and minerals. Many of those smaller railways are subsequently subsumed by the CPR and the Canadian National Railway upon later consolidations.'

For a period, the CPR sought to sell off some of its extensive land holdings in Western Canada to settlers and farmers. Originally, those settlers received title to all mines and minerals in the parcels acquired by them. In about 1902 however the CPR commenced reserving from its dispositions various mineral interests such as "petroleum" or "coal, petroleum and valuable stone". After about 1912 the CPR began to reserve all mines and minerals from subsequent dispositions. ${ }^{2}$ These mineral interests reserved by the CPR are now primarily in the name of PanCanadian Petroleum Limited, the ultimate successor in interest to the CPR.

1. D.E. Lewis and A.R. Thompson, Canadian Oil and Gas, vol. 1. (Toronto: Butterworths, 1971) at para. 26.

2. Ibid., para. 27. 
There was accordingly a period of approximately ten years during which the CPR created split titles to freehold mines and minerals in Western Canada, essentially divided between petroleum and natural gas. Since that time, ownership conflicts have arisen between these split title mineral owners. Most noteably, the Judicial Committee of the Privy Council was called on to resolve what, if any, natural gas was included in the CPR's reservation of petroleum from a transfer of the balance of its mineral rights in a parcel in the landmark case of Borys v. Canadian Pacific Railway and Imperial Oil Limited". More recently, divided ownership of petroleum and natural gas has raised the question of ownership of "evolved gas" that is the principal subject of this paper.

\section{WHAT IS EVOLVED GAS?}

Petroleum and natural gas are not always found together in the same reservoir. When those substances do occur in combination, the natural gas can be in either a liquid or a gaseous state. In its gas phase in a reservoir, natural gas is typically situate in a cap above the petroleum. The natural gas in such cap is frequently referred to as "associated gas" or "free gas". Natural gas can also be found in solution with petroleum. Solution gas occurs as a liquid in the reservoir but becomes a gas in two situations. Firstly, as solution gas is produced with petroleum from the reservoir the liquid natural gas vapourizes as it is drawn up the well bore as the petroleum/natural gas mixture becomes subject to lower temperatures and pressures at the surface compared to those in the reservoir. Secondly, solution gas can change from a liquid phase to a gas phase in the reservoir. The amount of natural gas in solution with petroleum in a reservoir is a function of the properties of the petroleum and the temperature and pressure in the reservoir from time to time. As petroleum is produced over time, the pressure in the reservoir declines allowing natural gas in solution to change from a liquid to a gas. Such vapourized gas physically separates from the petroleum in the reservoir. This natural gas that separates out of solution from petroleum in the reservoir as a result of declining pressure is commonly referred to as "evolved gas".

Evolved gas either forms a gas cap above the petroleum if there is no gas cap already there or commingles with the associated natural gas in the reservoir. When producing petroleum from such a reservoir, some of the natural gas in the gas cap emerges with the petroleum into the well bore. Evolved gas may accordingly continue to be produced together with the petroleum, notwithstanding that such natural gas has separated from the petroleum.

Periodic testing allows reservoir technicians to estimate the volumes of petroleum, solution gas, associated gas and evolved gas in a reservoir from time to time with greater or lesser degrees of accuracy.

In addition, the gas-oil ratio of the petroleum produced from time to time will indicate to such technicans whether the solution gas is escaping from the petroleum and whether natural gas in addition to solution gas is being produced. Any such additional volumes of natural gas will be either evolved gas or associated gas. 


\section{OWNERSHIP OF EVOLVED GAS}

Natural gas owners in split title situations have recently taken the position that they are the owners of any evolved gas that occurs in reservoirs containing petroleum and natural gas and that such mineral owners are accordingly entitled to be reimbursed for the proceeds of any such production (or royalties in respect thereof, as may be applicable) that may have been paid to the owners of the petroleum.

Arguments can be made for each mineral owners' entitlement to evolved gas production. The following is an analysis of the law applicable to this question.

\section{A. STATUTORY CONSIDERATIONS}

Two parts of Alberta's Oil and Gas Conservation Act ${ }^{4}$ appear to have some bearing on the question of ownership of evolved gas.

Alberta's Energy Resources Conservation Board (the "ERCB") classifies wells in this Province as "gas wells" or "oil wells" pursuant to the Oil and Gas Conservation Act and its associated regulations. The ERCB's classifications are based on a number of factors. This classification by the Energy Resources Conservation Board will determine such matters as Crown royalties, gas-oil penalties, production allowables and spacing unit requirements.

In addition, section 23 of the Oil and Gas Conservation Act allows the ERCB to provide for the rateable take of natural gas by an ERCB order. That section reads as follows:

The Board may, by order, restrict:

(a) the amount of gas, or

(b) where gas is produced in association with oil, the amount of gas and oil,

that may be produced during a period defined in the order from a pool in Alberta, and the restriction may be imposed by either or both of the following means:

(c) by limiting, if the limitation appears to be necessary, the total amount of gas that may be produced from the pool or part of the pool, having regard to the demand for gas from the pool or to the efficient use of gas for the production of oil, or to both of those considerations;

(d) by distributing the amount of gas that may be produced from the pool or part of the pool in an equitable manner among the wells or groups of wells in the pool for the purpose of giving each well owner the opportunity of receiving his share of gas in the pool.

The classification of a well for statutory or administrative purposes as a gas well or an oil well and the ERCB's power to distribute the natural gas produced in an equitable manner would not, however, be determinative of who owns evolved gas in a split title scenario. The Oil and Gas Conservation Act and its associated regulations does not expressly give jurisdiction to the ERCB to deal with the issue of ownership of evolved gas in respect of freehold mineral titles. Conservation statutes are designed to prevent property waste and to protect correlative rights, not to determine mineral ownership. It is not within the purpose of conservation agencies to determine property rights or within the powers of such agencies to do so. This position is consistent 
with the position taken by the courts in Texas in the recent decisions of Amarillo Oil Company v. Energy-Agri Products, Inc. ${ }^{\text {ta }}$ and Dorchester Gas Producing Co. v. Harlow Corp. ${ }^{4 b}$

\section{B. AT COMMON LAW}

Since the statutory framework in Alberta does not resolve the issue of ownership of evolved gas, the common law must be reviewed to provide an answer to this question.

\section{The Borys Decision}

Canadian jurisprudence does not appear to have directly considered the ownership of evolved gas. Although natural gas owners in split title situations have contended that the Borys ${ }^{5}$ case is authority for the conclusion that evolved gas is owned by the owners of the natural gas, that case did not decide this issue.

The Borys case involved a situation characteristic of that described above where ownership of petroleum and natural gas was split pursuant to a reservation of the CPR of the petroleum underlying the lands in question from a conveyance of the fee simple title. The property reserved by the CPR from the transfer was "all coal, petroleum and valuable stone." The central issue considered in the Borys case was what substances were included in the CPR's petroleum reservation. Mr. Borys had claimed to be the owner of all natural gas underlying his lands, whether such natural gas was solution gas or associated gas. The CPR and Imperial Oil Limited as owner and lessee respectively of the petroleum underlying $\mathrm{Mr}$. Borys' lands claimed that all natural gas in the formation was included in the petroleum reserved to the CPR whether such natural gas was in solution with the petroleum or was associated gas. Alternatively, the CPR and Imperial Oil Limited claimed ownership of all natural gas in the reservoir in a liquid phase whether or not such natural gas was in solution with the petroleum.

The Judicial Committee of the Privy Council evidenced an appreciation of the concept of evolved gas in rendering its decision. In the judgment of the Privy Council, delivered by Lord Porter, it was stated: ${ }^{6}$

The difficulty of distinguishing between what is gas and what is petroleum is most easily seen when the ratio of what is fluid in the untapped container to what is gaseous is compared with the ratio of one to the other when the substance is stabilized on the surface. But the difficulty goes deeper because as the oil is extracted from the reservoir the ratio almost inevitably changes, the gas increasing as the pressure and temperature are reduced. (emphasis added).

As stated above, no decision was expressly made by the Privy Council as to the ownership of such evolved gas. However, certain of the dicta of the Privy Council may provide a key to the resolution of this issue.

4a. Unreported, 8 March 1989, Supreme Court of Texas.

4b. 743 S.W.2d. (Tex. App. - Amarillo 1978) 243.

5. Supra, note 3.

6. Ibid., at 554 . 
The Privy Council in Borys concluded that the reservation of petroleum in that case included solution gas despite Mr. Borys' claim to the contrary. The Privy Council adopted the findings of Parlee J.A. in the majority judgment of the Alberta Supreme Court Appellate Division ${ }^{7}$ with regard to this matter. The following portions of Mr. Justice Parlee's judgment were quoted by the Privy Council: ${ }^{8}$

What was reserved to the railway company was petroleum in the earth and not a substance when it reached the surface. It is true that, by change of pressure and temperature, gas is released from solution when the liquid is brought to the surface but such a change ought not to affect the original ownership.

$$
\text { - } \bullet
$$

In my opinion, all the petroleum reserved, including as hydrocarbons in solution or contained in the liquid in the ground, is the property of the defendants [CPR and Imperial Oil] who are entitled to do as they like with it, subject, of course, to the observance of all relevant statutory provisions and regulations.

Mr. Justice Parlee went on to say that: ${ }^{9}$

All gas not included in the reservation of petroleum as indicated is the property of the plaintiff [Mr. Borys].

What Mr. Borys obtained insofar as ownership of natural gas rights was concerned, by the conveyance of such rights from the CPR, was restricted to whatever natural gas was not included in the minerals reserved by the CPR.

The question answered by the Privy Council was not whether petroleum and natural gas are separate substances but rather what was included in the reservation of petroleum by the CPR. The Privy Council and the courts of Alberta that reviewed this question all acknowledged that on a scientific or technical analysis petroleum and natural gas were in fact distinct substances. Their decision, however, was based on the vernacular meaning of "petroleum" in the CPR's reservation and not the scientific or technical meaning of that term and their observation that none of the parties to the transfer would have differentiated between the petroleum and the natural gas in solution in the reservoir. In the Privy Council's view, all such parties would have included all liquid substances contained in such petroleum in the property reserved by the CPR from its transfer.

The question to be determined regarding ownership of evolved gas is whether such ownership is established at the date of the conveyance which resulted in separate titles to petroleum and natural gas or whether such ownership is to be determined from time to time taking into account the changes in the proprotions of petroleum and natural gas in the reservoir as evolved gas occurs.

The Borys case appears to say that if at any time and from time to time evolved gas occurs in the formation, then the owner of the petroleum would no longer be entitled to such natural gas on the basis that evolved gas is no longer in solution with the petroleum. This can be inferred from the following passage from the judgment of Lord Porter: 10

The answer, say the respondents [CPR and Imperial Oil], is to be found in a wide interpretation of the word petroleum, which, it is maintained, includes all kinds of hydrocarbons whether in liquid or gaseous form. On the other hand, the appellant [Mr. Borys] contends that gas is gas whether in solution with oil in a liquid form or in a gaseous state. The test is what is liquid and what is gas at the conventional figure of $60^{\circ}$ Fahrenheit and 4.65 pressure, i.e., its state at what is a mean temperature and a mean pressure on the surface.

The learned Chief Justice [in the trial judgment] took the latter view; the Court of Appeal adopted a compromise, viz., the condition of the substance as it emerges from time to time from the reservoir. (emphasis added).

7. [1952] 3 D.L.R. 218. The judgment of the Trial Division of the Supreme Court is reported at (1951), 2 W.W.R. (N.S.) 145. The decision of the Appellate Division was appealed per saltum to the Privy Council.

8. Supra, note 3 at 556.

9. Supra, note 7 at 230.

10. Supra, note 3 at 554 . 
As stated above, the conclusion of the Appellate Division as to what was included in a reservation of petroleum was adopted by the Privy Council.

The "condition" of petroleum as it emerges from time to time from the reservoir into the well bore would not include any evolved gas that had escaped from the petroleum prior to such petroleum being produced. On that basis evolved gas would be owned by the owner of the natural gas.

It could be possible however to construe the Borys case as supporting the view that evolved gas remains the property of the owner of the petroleum notwithstanding that such natural gas has separated from the petroleum in the reservoir. The basis of this conclusion would be that the relevant time to determine what natural gas is included in the petroleum reserved to the CPR is the time that such reservation was made, rather than making that determination from time to time as petroleum emerges from the reservoir. Mr. Justice Parlee spoke of "original ownership" in the portion of his judgment referred to above, where he concluded that the petroleum reserved included natural gas in solution nothwithstanding that by the time the petroleum was brought to the surface such natural gas was released from solution. As evolved gas was "originally owned" by the CPR a similar analysis may apply. Also, all that the owner of the natural gas acquired from the CPR was whatever natural gas was not included in the petroleum reservation. Accordingly, it could be argued that natural gas in solution with petroleum at the time of the reservation, whether or not such natural gas remained in solution in the reservoir after that time was, and would remain, the property of the owner of the petroleum.

This latter interpretation, in our view, is not a correct application of the principles of the Borys case to the question of ownership of evolved gas. In the Borys case, Mr. Borys had sought and obtained at trial a permanent injunction preventing Imperial Oil from producing its petroleum reserves. The injunction was initially granted because production of the petroleum would adversely affect natural gas found in the producing reservoir to the detriment of the owner of the natural gas. In the early 1950 's when Imperial Oil was attempting to produce the petroleum reserves underlying Mr. Borys' lands, the commercial value of natural gas was less immediate than petroleum and the gathering, processing and transportation infrastructures required to market such substances were not in place. As a result, any solution gas or associated gas produced with the petroleum would probably have been flared. On appeal the injunction was removed. The Privy Council's decision in the Borys case allowed petroleum production in the Province of Alberta in a manner consistent with then current good oilfield production and conservation practices. If the decision had been made in Mr. Borys' favour, the petroleum reserves underlying those lands would have been shut in until Imperial Oil and Mr. Borys came to agreement compensating Mr. Borys for the loss of his property. The decision of the Privy Council enabled Imperial Oil to produce the petroleum reserves leased to it by the CPR even though Imperial Oil did not also own or lease the natural gas that was found in the reservoir together with the petroleum and even though natural gas would be lost as a result of such production activity.

It was not unreasonable in the economic and other circumstances that prevailed at that time to find that solution gas was part of the substances reserved to the owner of the petroleum, even if such finding was detrimental to the owner of the natural gas. The courts today would not however, in our view, extend the Borys principles any further than required. Where petroleum can be produced notwithstanding that evolved gas has escaped from the petroleum while the petroleum is still in the reservoir, there is no compelling practical reason or basis in law why the owner of the petroleum should continue to be entitled to such natural gas. 


\section{The Rule of Capture}

Ownership of petroleum, natural gas or other fugacious substances is not absolute while such substances remain in the ground. Under the rule of capture the owner of mineral rights to a particular property acquires title to all petroleum and natural gas produced from such property even though such petroleum and natural gas may in part be drained from adjoining lands.

The Borys decision confirms recognition of this rule in Canada. Lord Porter observed in his judgment that: ${ }^{10 a}$

If any of the three substances [gas, oil and water] is withdrawn from a portion of the property which does not belong to the appellant but lies within the same container and any oil or gas situated in his property thereby filters from it to the surrounding lands, admittedly he has no remedy. So, also, if any substance is withdrawn from his property, thereby causing any fugacious matter to enter his land, the surrounding owners have no remedy against him. The only safeguard is to be the first one to get to work, in which case those who make the recovery become owners of the material which they withdraw from any well which is situated on their property or from which they have authority to draw.

The rule of capture has been modified in Canada by the recognition of correlative rights of persons holding interests in a common reservoir and by conservation laws and regulations that provide for drilling and production spacing units, the prorationing and control of production and the regulation of transportation of production so as to permit equality of access to markets.

This rule as so modified would not however allow the owner of the petroleum in a producing reservoir to claim title to any natural gas produced from that same reservoir where natural gas underlying the lands in question is owned by another party. The rule of capture deals with drainage from adjoining parcels (or, put another way, different ownership interests across spacing unit boundaries) rather than dealing with ownership conflicts in the same parcel. Such rule recognizes the impossibility of determining whether any production from a reservoir is from the well owner's property or an adjoining property where the reservoir underlies more than one such property. It is , however, possible to distinguish between liquids and gases and to measure the extent to which natural gas in excess of natural gas in solution with petroleum is produced from time to time.

If the rule of capture were applied to split title ownership disputes in the context of evolved gas, that rule would dictate that the title of the owner of the petroleum to solution gas while in the reservoir (which title was established pursuant to the Borys decision) is subject to being defeated if such natural gas escapes from solution with the petroleum before such petroleum enters the well bore. In that event the owner of the petroleum would have failed to capture such natural gas while it was contained in the petroleum. It should be emphasized in this analysis that the point of reference for application of the rule of capture should be at the well bore where control of the production is in fact obtained. This result is consistent with our interpretation of the applicable principles of the Borys decision and further substantiates the view that evolved gas would be owned by the owner of the natural gas.

\section{American Authorities}

A review of the American authorities suggests that the U.S. courts have not directly considered the issue of ownership of evolved gas either. One decision of interest is the judgment of the Commission of Appeals of Texas in Lone Star Gas Co. v. Stine".

10a. Ibid., at 550 .

11. 41 S.W.2d. (Tex. Com. App. 1931) 48, 49, 82 A.L.R., 1299. 
In that case it was held that a conveyance of "all natural gas" included "all the substances that come from the well as gas, and that regardless of whether such gas be wet or dry". '? "Wet gas" contains vapourized petroleum substances. "Dry gas" is free of such substances. The split title to petroleum and natural gas in that case arose by virtue of a conveyance by the fee simple owner to a gas company of:

All our rights. title and interest. ownership and claim, both present and prospective, in all natural gas in and under the following tract and parcels of land.

At issue was whether the conveyance included gasoline manufactured by the gas company from natural gas produced from the subject land through an absorption and extraction process. The court held that such gasoline was included within the scope of the conveyance by reason of the fact that it was in the form of natural gas when it came from the well. The gas company could do what it wanted with such natural gas upon removal from the well.

The Lone Star Gas Co. v. Stine decision has been cited in a number of cases for the above noted principle. (See Amoco Production Company v. State of Wyoming ${ }^{13}$, Amerada Hess Corporation v. Conrad'4, Sun Oil Company v. Madeley's, W.O. Blocker v. Christie, Mitchell \& Mitchell Co. ${ }^{16}$, Sowell v. Natural Gas Pipeline Co. of America ${ }^{17}$, Northern Natural Gas Company v. Grounds ${ }^{18}$, Navajo Tribe of Indians v. U.S. ${ }^{19}$, Vernon v. Union Oil Company of Califormia ${ }^{20}$, Mapco, Inc. v. Pioneer Corporation'1).

The Lone Star Gas Co. v. Stine decision, while not directly addressing the issue of ownership of evolved gas, does suggest that the question of ownership should be determined at the well head and not after processing of the produced substances. If the test to be employed in determining the ownership of evolved gas is that suggested by the court in Lone Star Gas Co. v. Stine (that is, at the well head as opposed to determining whether the natural gas remained in solution when the petroleum entered the well bore), the issue of ownership of evolved gas would be resolved in favour of the holder of the natural gas title. Such gas would have to be in solution with the petroleum at the well head in order for it to be owned by the owner of the petroleum title.

R.A. Midkiff, in an article entitled "Phase Severance of Gas Rights from Oil Rights" 22 is critical of the "surface distribution test" enunciated in Lone Star Gas Co. v. Stine. In Mr. Midkiff's opinion, the surface distribution test is "untenable in ownership jurisdictions and is inaccurate and inappropriate in both non-ownership and ownership jurisdictions" ${ }^{23} \mathrm{Mr}$. Midkiff's distinction between ownership and

12. Ibid. at 49.

13. 751 P.2d. (Wyo. 1988) 379.

14. 410 N.W.2d. (N.D. 1978) 124.

15. 626 S.W.2d. (Tex. Sup. Ct. 1981$) 726$.

16. 340 S.W.2d. (Tex. Div. App. - Ft. Worth 1960) 320.

17. 789 F.2d. (5th Cir. 1986) 1151.

18. 441 F.2d. (Ct. App. Kan. 1971) 704. 292 F.Supp. (Dist. Ct. Kan. 1968) 619.

19. 364 F.2d. (Ct. Cl. 1966) 320.

20. 270 F.2d. (Ct. App. Tex. 1959) 441.

21. 447 F. Supp. (Dist. Ct. Tex. 1978) 143.

22. (1984), 63 Texas L. Rev. 133.

23. Ibid., at 162. 
non-ownership jurisdictions relates to the position taken by courts in some states that due to its fugacious nature oil and gas cannot be owned while in the ground but is only capable of ownership once captured on the surface. The question as to whether Canada, and in particular Alberta, is an ownership or non-ownership jurisdiction has not yet been finally judically resolved. ${ }^{23 a}$

A second criticism offered by Mr. Midkiff of the surface determination test proposed by the court in Lone Star Gas Co. v. Stine is that "typical granting language indicates that ownership transfer should occur in the reservoir".${ }^{24}$ In Mr. Midkiff's opinion:25

The important point is that if the court did resolve the ownership issue, it chose the surface as the reference point for determination without any reasoned consideration of either its general utility or its specific contravention of ownership jurisdiction theory.

Mr. Midkiff expresses the conclusion that the issue of ownership of oil and natural gas in the reservoir where title to the oil and natural gas phases has been severed has not been fully addressed by the American judiciary. Mr. Midkiff suggests that the issue should be resolved through phase allocation, using as the reference point for making such allocation the entrance to the well bore. The natural gas estate would include reservoir fluid produced from the well which existed in the gas phase at the reference point while the oil estate would include any natural gas in the liquid phase at the reference point. ${ }^{26}$

It would appear that Texas courts, while expressing that the governing principle remains one of the ascertainment of the intention of the parties to the conveyance, have accepted Mr. Midkiff's concept of phase allocation. ${ }^{26 a}$ In one recent decision, it was held that a conveyance of "oil and oil rights" included "casinghead gas" which was defined as "gas and/or vapour indigenous to an oil stratum and produced from such stratum with oil" "26b (which is referred to in this paper as "solution gas").

Mr. Midkiff expresses the further opinion that the phase allocation be made on a periodic basis rather than pursuant to an initial one time determination. His rationale, which provides significant insight into the issues addressed by this paper, is as follows: ${ }^{27}$

There are two possibilities: the basis can be determined either by a single test of each well in its virgin condition upon completion, or by multiple tests of each well at periodic intervals over the life of the reservoir. The time of testing is critical, because the phase distribution of production from a well can change as the reservoir ages.

Although some judicial support exists for a one-time determination, the better reasoning supports periodic testing. First, virgin testing would lead to absurd results when a well changes classification. Second, periodic testing is in harmony with the legislative mandates to maximize ultimate recovery of reserves and to prevent waste. To ignore subsequent changes in reservoir phase distribution could lead to conflicts between established operator methods and efficient recovery of reservoir contents. Only periodic testing is sensitive to the rate of production, the age of the reservoir, and other factors critical to efficient reservoir recovery.

23a. D.E. Lewis and A.R. Thompson, supra note 1, paras. 30 et. seq.

24. Supra, note 22, at 162 .

25. Ibid., at 163.

26. Ibid., at 165 .

26a. Amarillo Oil Company v. Energy-Agri Products, Inc., supra, note 4a; and Dorchester Gas Producing Co. v. Harlow Corp., supra, note $4 \mathrm{~b}$.

26b. Dorchester Gas Producing Co. v. Harlow Corp. , ibid. at 250.

27. Supra, note 22, at 172 to 175 . 
Third, consistent adherence to the rule of capture supports periodic testing. Because initial testing would freeze the allocation formula for the life of each well at the phase distribution existing in the well as first tested after completion, it effectively renders the phase owners liable to each other for changes in reservoir phase distribution that occur with production, even though the cumulative production of all producers from the reservoir causes the change. An anomaly results: initial testing creates liability between the phase owners in the same tract, but the rule of capture precludes liability among landowners in the same reservoir and precludes liability between the landowners and the phase owners. Moreover, initial testing disrupts the normal incentives for each phase owner to drill upon the tract. Periodic testing avoids these problems by adjusting the allocation formula to reflect changes in reservoir phase distribution and by creating non-liability between phase owners for such changes. Thus, each phase owner would own his phase as it currently exists in the reservoir at the time produced into his well, without regard to phase changes prior to capture.

Fourth, periodic testing protects correlative rights. Each landowner must be afforded the reasonable opportunity to recover his fair share of the oil or gas under his land. To prevent waste, conservation statutes circumscribe this right. In the modern context, the prevention of waste involves maximizing ultimate BTU recovery from each reservoir. Because crude oil possesses a higher BTU value per unit volume than natural gas, conservation regulations restrict gas production in favor of maximizing oil recovery. As a result, proration rules institute a substantial bias favoring oil production over gas production. In a typical two-phase reservoir, the oil estate withdraws more BTUs of production, and hence receives more revenue, than the gas estate. Although the gas in the reservoir eventually may be recovered after the oil reserves have perished, the oil bias presents the classic annuity problem. When the two phases possess roughly equal amounts of hydrocarbons, the present value of the income stream from reduced current and future gas production may be less than the present value of the income stream from current and future oil production. Thus, the gas owner does not receive his fair share. Periodic testing, however, would tend to offset the oil bias. Because most reservoir changes increase the BTU content of the gas phase, periodic testing would place ownership of the incremental BTU content in the gas estate, reducing the impact of the oil bias.

Finally, ambiguous grants should be construed according to the probable intent of the parties. In real terms, a deed or lease conveys the right to appropriate minerals. If the parties could enter the reservoir and physically mine its contents, they probably would divide ownership on the basis of the phases present in the reservoir at the time of capture. Thus, continuous testing would best reflect the parties' intent. Periodic testing is the most practical alternative to continuous testing.

In effect, Mr. Midkiff's conclusion is that the issue of ownership of evolved gas should be resolved in favour of the owner of the natural gas. This view is consistent with our conclusion with respect to Canadian authorities on the ownership of evolved gas.

\section{EFFECT OF ERRORS IN PAYMENT}

The issue regarding ownership of evolved gas is a relatively recent controversy. Operators of wells drilled by owners of petroleum or by lessees of petroleum rights may have been producing evolved gas for some period of time under the legitimate but perhaps mistaken belief that they were entitled to any proceeds of such production and unaware that the owners of the natural gas may challenge such entitlement.

Typically petroleum is the first substance produced from a reservoir containing both petroleum and natural gas. This is required in order to maximize the recovery of each of those substances. Solution gas, evolved gas and quantities of associated gas may also be produced from such well as the petroleum is produced. If the operator of a well producing petroleum from a reservoir containing both petroleum and natural gas has not recognized that evolved gas is also being produced or if the owner and lessee of the petroleum have mistakenly assumed that they are entitled to any such evolved gas, the owner of the natural gas may not have been paid the royalties or other amounts due to it. A variety of consequences arising from such non-payment must be considered depending on whether the petroleum or the natural gas rights 
have been leased and whether or not the lessee of the petroleum rights also leases the natural gas rights. Those considerations include:

(a) the effect on the natural gas lease where royalties to be paid thereunder have been either underpaid or not paid at all by reason of a mistake as to ownership of evolved gas where the petroleum and natural gas are leased by the same person;

(b) whether such lessee can recover monies paid in mistake; and

(c) what course of action the lessee should take with respect to future royalty payments relating to evolved gas.

Following are some brief observations regarding these questions.

\section{A. THE STATUS OF THE NATURAL GAS LEASE}

Assuming that the same person has leased both the petroleum and the natural gas from the respective owners of those minerals in a split title situation, would the natural gas lease terminate by reason of the fact that the lessee failed to pay, or alternatively, underpaid royalties to the lessor of the natural gas rights on the evolved gas produced? To the extent that royalties with respect to any such production of evolved gas have been paid to the petroleum lessor rather than to the natural gas lessor, the lessee would be in default under the natural gas lease. Each lease should be carefully reviewed to ascertain what is provided for in such event. However, most petroleum and natural gas leases contain default provisions which preclude the automatic termination of any such lease if the lessee is in default thereunder. Notice of the default is usually required to be given by the lessor to the lessee. The lessee is then given a stipulated period of time following such notice in which to remedy the default. Leases containing such default provisions will not terminate until the expiry of the stipulated grace period. Some mineral leases go further than that. They provide that the lease will not be terminated or forfeited unless and until it has been finally judicially determined that a default has in fact occurred and that the lessee has been given a reasonable period of time following such determination to rectify the default. Still other leases provide that the lease will not terminate by reason of a default on the part of the lessee where a well capable of producing leased substances is situated on the leased lands. In such event the lessor's remedy is restricted to damages.

Where the natural gas lease in question contains default provisions similar to those described in the preceding paragraph, the non-payment or under payment of royalties by the lessee to the lessor in respect of the production of evolved gas would not result in the automatic termination of the mineral lease.

In the event that the lease in question does not contain a default provision similar to those described above and the mineral lessor takes the position that the lease is forfeited by reason of the default of the lessee in payment of the royalties payable thereunder, resort would have to be had to the common law principles relating to repudiation of lease agreements to determine whether a failure to pay royalties in such circumstances would entitle the lessor to terminate the lease. In the event that it is found that the lessor was entitled to terminate the lease, the lessee, under appropriate circumstances, should give consideration to a plea for relief from forfeiture pursuant to section 10 of the Judicature Act ${ }^{27 \mathrm{a}}$ which provides the court with the general jurisdiction to relieve against "all penalties and forfeitures". 


\section{B. RECOVERY OF MONIES PAID IN ERROR}

Royalties on evolved gas production typically have been paid to the owner of the petroleum rather than to the owner of the natural gas in split title situations. If it is determined that the natural gas owner rather than the petroleum owner is entitled to such royalties, the party making such payments will want to recover any amounts paid to the owner of the petroleum.

The traditional method of analyzing whether money mistakenly paid can be recovered was to determine whether such monies were paid as a result of a mistake of fact or a mistake of law. If monies were paid under a mistake of fact they may be recoverable. If however monies were paid under a mistake of law they are generally not recoverable.

There are two Canadian decisions dealing with attempts to recover overpayments of royalties. The first, Rural Municipality of Storthoaks v. Mobil Oil Canada Ltd. ${ }^{28}$, arose when the accounting department of Mobil Oil Canada Ltd. mistakenly continued to make royalty payments after Mobil had surrendered the leases under which the royalties were payable. The court there held that the mistake was one of fact and that accordingly the money paid could be recovered. This result was reached even though other Mobil employees knew that the leases in question had been surrendered.

The second decision involving overpayment of royalties is Norcen International $L t d$. v. Suncor Inc. ${ }^{29}$. The learned trial judge in that case found that an improper payment of royalties on account of federal petroleum compensation payments was a mistake of fact. Prowse J. states: ${ }^{29_{\mathrm{a}}}$

I find the royalty paid by the defendant . . . was not paid under a mistake of law but as a result of the accounting department employees using the wrong formula in computing the royalty due to the omission of the defendant to consider or construe cl. 3.1(f) of the sublease.

Although that decision was appealed, the portion of the judgment referred to above was not affected.

Any errors in royalty payments by a lessee regarding evolved gas production would likely be considered to have been based on a mistake of fact if the lessee thought such evolved gas was solution gas. However, if the lessee at the time of payment knew that the gas that had been produced was in fact evolved gas but paid royalties in respect of such gas to the owner of the petroleum thinking that the owner of the petroleum was entitled to receive the royalty in respect of such natural gas production, then the lessee may be said to have paid the royalty under a mistake of law.

It may also be possible for the lessee to recover any monies improperly paid to the owner of the petroleum regardless of whether such monies were paid under a mistake of fact or a mistake of law on the basis of unjust enrichment. In fact, a majority of the Supreme Court of Canada in Air Canada v. British Columbia ${ }^{30}$ recently expressed the view that the distinction between mistakes of fact and mistakes of law, insofar as it relates to the right of recovery of money paid under a mistake, should be abolished with such recovery instead being assessed within the context of the principles of the law of restitution and unjust enrichment.

28. (1975), 55 D.L.R. (3d) 1 (S.C.C.).

29. $[1985] 4$ W.W.R. 35 (Alta. Q.B.).

29a. Ibid. at 60.

30. (1989), 59 D.L.R. (4th) 161 (S.C.C.). 
Where the petroleum lessee does not also lease the natural gas, such lessee will have to pay the natural gas lessee for any evolved gas produced if it is determined that the owner of the natural gas is entitled to such production.

\section{FURTHER ROYALTIES ON EVOLVED GAS}

Where a lessee of petroleum in a split title situation has discovered that evolved gas is being produced, the prudent course of action for such lessee to take would be to not pay the owner of the petroleum any further royalties on evolved gas without the agreement of the owner of the petroleum that any such payments are made on a "without prejudice"' basis and that such payments are subject to return together with interest thereon in the event that the owner of the petroleum is determined to be not the owner of the evolved gas. In the event such an arrangement cannot be agreed to or in the event the natural gas lessor threatens termination of the natural gas lease, then the petroleum lessee may want to consider interpleading any such royalty payments and obtain such declarations from the court as may be required to ensure the ongoing validity of the petroleum lease and the natural gas lease while a dispute over ownership of the evolved gas is being resolved. Without either a "without prejudice" agreement or interpleading the royalties in question, the petroleum lessee may not be able to recover payments made to the owner of the petroleum from and after the date on which the petroleum lessee became aware that the natural gas being produced was not solution gas but rather was evolved gas.

\section{CONCLUSIONS}

Disputes between owners of petroleum and owners of natural gas regarding entitlement to evolved gas have to date been settled without the issue having been considered by the courts. Thus far the economics of these controversies have favoured negotiated, rather than court-imposed, solutions.

There are clearly various arguments that can be advanced as to whether the owner of petroleum or the owner of natural gas should be entitled to any evolved gas that may occur in a reservoir containing petroleum and natural gas. However, based on the discussion above, our conclusion is that evolved gas is owned by the owner of the natural gas.

Until the issue of ownership of evolved gas has been judicially resolved, the question will remain the subject of controversy. In the interim, given the problems that may arise from production of evolved gas, all parties having interests in split title properties should review their positions to ensure that they are able to protect their interests in the event such ownership controversy occurs. 